\title{
On the Anatomy and Relationships of New or Little known British Actiniaria.
}

\author{
By \\ E. Mary Stephenson, M.Sc., \\ Biology Department, King's College for Women.
}

With 24 Figures in the Text.

\section{INTRODUCTION.}

THIs paper contains anatomical descriptions of some British species whose systematic position has hitherto been uncertain because of the absence of detailed knowledge of their structure. To these descriptions are added notes on anatomical points of interest connected with other species.

Some of the facts gained have a general systematic bearing which will be pointed out as they occur in connection with the descriptions, or in the discussion at the end of the paper. I am indebted to Dr. Allen, Mr. W. Edgar Evans, Mr. R. Elmhirst, Miss M. Delap, and Dr. T. A. Stephenson for material, and to Dr. Esdaile for valuable guidance.

1. Sagartia coccinea Gosse, 1858, p. 416.

(Not Actinia coccinia Müller, 1776, p. 231.)

Sagartia coccinia has usually been accepted as a species of small size, not reaching the dimensions of such forms as $S$. miniata, S. viduata, etc. During 1924, however, some specimens were taken at Millport which considerably exceed the size supposed to be characteristic of the species, showing that it may be as large as the more common forms under suitable conditions.

I have been able to examine 3 specimens, 1 from Millport and 2 from Valentia Island, co. Kerry.

The coloration and external characters have been described elsewhere (Gosse, 1860, p. 84, Pl. V, Fig. 4, and Walton, 1908, p. 208) ; it need only be remarked here that externally the species is a perfectly typical Sagartia, being one of the species without suckers, and being characterised, among other things, by its lacerate basal outline and constant habit of asexual reproduction by basal fragmentation. 
The number of tentacles in this species is variable, in correlation with its habit of fragmentation ; the formula may run $6,6,12$, etc., $8,8,16$, etc., 10, 10, 20, etc., and so on.

The following is a description of one of the Valentia specimens.

Expanse of disc and tentacles, during life, $3 \mathrm{~cm}$. ; total height of expanded animal, $2 \cdot 2 \mathrm{~cm}$. or more. Tentacles $6,6,12,24$, and a few additional ones (incomplete fifth cycle). Mesenteries in 3 cycles, with a few small additional mesenteries developing. Perfect mesenteries, 12 pairs,

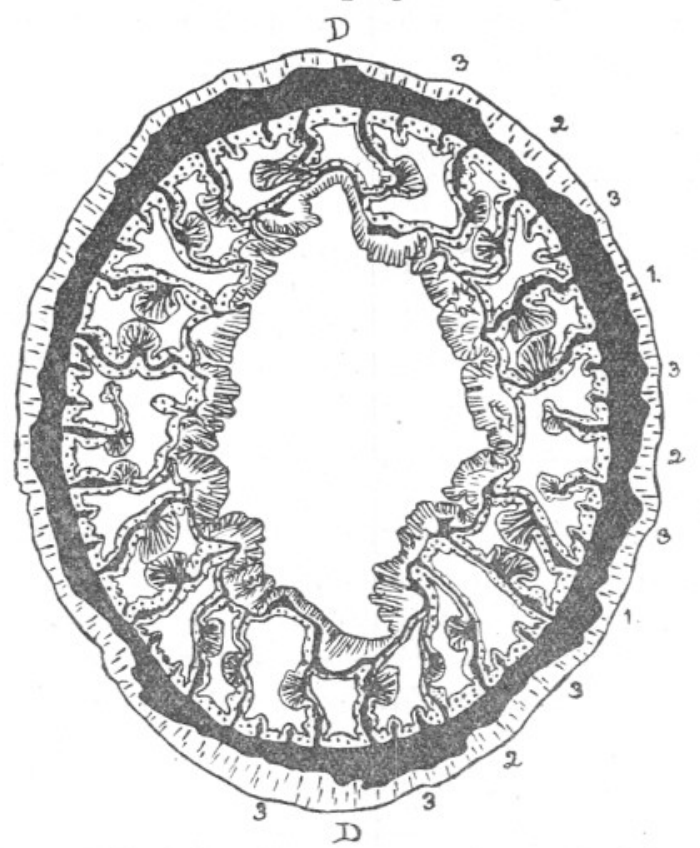

FIG. 1. T.S. of Sagartia coccinea, near lower end of throat.

D. Directives: numbers 1,2 and 3 indicate mesentery cycles.

including 2 pairs of directives connected with 2 siphonoglyphs. Imperfect mesenteries, 12 pairs, and a few additional young pairs. The cycles of mesenteries grade into each other, and are not distinguished into macrocnemes and microcnemes. Perfect mesenteries with strong circumscriptdiffuse retractors, older imperfect mesenteries with slightly developed ones. Retractors strongest on the 6 pairs of primary mesenteries ; their individual muscle-processes stout, slightly branched, high. Perfect mesenteries with large parietal and small labial stomata, occurring within a narrow zone immediately below the top of the throat. Filaments occur on the mesenteries of cycles 1-3 inclusive, being well developed on the first two cycles. The reticulate area of the typical trefoil region is well marked, and ciliated streaks are present. Acontia well developed, 
occurring on all mesenteries of cycles 1 and 2 , and on most of those of cycle 3. Longitudinal musculature of tentacles ectodermal, its processes well branched. Gonads not developed. Large cinclides present, occurring in a zone about $\cdot 6 \mathrm{~mm}$. deep (in the preserved specimen), which starts at about the lower edge of the sphincter. Only 8 cinclides are present, 1 in each secondary endocoel, and 2 additional ones in primary endocoels. I cannot detect any cinclides near the edge of the base, such as occur in some Sagartias. The cinclides are all principally endodermal evaginations. A section of one is shown in Fig. 3 (this being a longitudinal section through part of the body wall of the other Valentia specimen). It will be seen that the thick part of the mesogloea (black) is completely interrupted, allowing the ectoderm and endoderm to come practically into contact with each other, only an attenuated diaphragm lying between them. None of the cinclides have an actual canal perforating the epithelium itself, all the way through; but such a canal is by no means a universal feature of cinclides, which are often, instead of being actual pores, simply organised soft spots where the mesogloea is interrupted or reduced to very little, and which may be burst open if pressure within the coelenteron.becomes too great. From Fig. 3 it may be seen that there is a partial canal running out from the endodermal side and ending blindly; and that the greater part of the epithelium of the cinclis is endoderm, this being the layer initiating the cinclis in this case. Fig. 1 shows a complete transverse section of the specimen described above, at the level of the throat.

The other Valentia specimen was sectionised vertically to show the structure of the sphincter. This is strong, diffuse, mesogloeal, lying towards the inner side of the mesogloea, but separated from the sheet of endodermal circular muscle by a narrow band of muscle-free mesogloea. The average depth of the spincter (preserved) is $\cdot 6 \mathrm{~mm}$., this being about 8 per cent of the whole height of the column. A typical section of the sphincter is shown in Fig. 2. The cinclides seen in this specimen have the same structure as in the other.

The large Millport specimen has the mesenteries arranged as in the one described; but there are more of them, the fourth cycle being fully present, and part of a fifth also. This individual, moreover, is fertile, gonads occurring on cycles 1-3 inclusive, and also on the directives.

It is clear from the above data that $S$. coccinea possesses all the qualifications necessary for a typical member of the genus Sagartia, and its systematic position can now be established. It has a definite adherent base, soft smooth body, tentaculate margin, a submarginal zone of cinclides, a limited number of tentacles with ectoderma! longitudinal muscle, gonads on all the older mesenteries, numerous mesenteries perfect, strong 
retractors, acontia, no division of mesenteries into macro- and microcnemes, and a strong mesogloeal sphincter.

Carlgren has suggested (1894, p. 96) that possibly his variety undata $\beta$ of Sagartia undata Muiller is identical with Gosse's (not Müller's) S. coccinea. It is difficult, without seeing living specimens, to be quite sure about the identity or otherwise of the British and non-British forms. Carlgren's description of the colouring of his v. undata $\beta$ certainly seems more like the British $S$. coccinea than that of his other varieties (v. undata a and v. troglodytes), and his var. troglodytes may be our British S. troglodytes. Whatever the truth of this may be, however, the situation is clear with

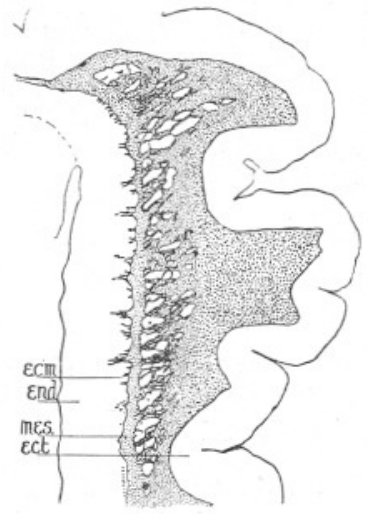

FIG. 2.-Sphincter of Sagartia coccinea. e.c.m. endodermal circular muscle: ect. ectoderm : end. endoderm: mes. mesoglœa.

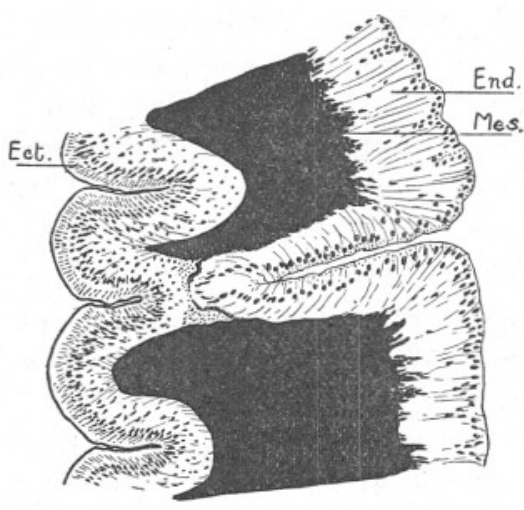

FIg. 3.-Cinclis of Sagartia coccinea, shown in L.S.

Ect. ectoderm : End. endoderm : Mes. mesoglœa.

regard to British species; here we have $S$. coccinea Gosse, which is one thing, and S. troglodytes, which is another; they are not varieties of the same form. Anatomically $S$. coccinea seems to agree with Carlgren's description of undata $\beta$ in some directions, but not as regards the cinclides ; and the sphincter also seems rather different.

2. Metridium pallidum (Holdsworth, 1855, p. 236, Pl. V, 4).

The external features of this species (usually called Sagartia pallida) have been described by Gosse (1860, p. 78, Pl. III, Figs. 4 and 5) and by W. Edgar Evans (1924, p. 185 et seq.), as well as by Holdsworth. I am indebted to Mr. Evans for 2 specimens, 1 from Torquay (var. cana Gosse), the other from Church Island, Valentia (var. rufa Gosse), collected by Miss Delap.

The following is a description of the Torquay specimen. Diameter of base, during life, $1.2 \mathrm{~cm}$., the expanse of disc and tentacles the same 
or more. Mesenteries in 4 cycles, with a few small additional mesenteries near the base. Sixteen perfect mesenteries are present, forming 7 pairs and 2 half-pairs; but these do not all belong to the first cycle, being irregularly distributed, as is often the case in forms which, like $M$. pallidum, reproduce asexually. The first cycle contains 7 pairs of mesenteries, 6 of these being perfect, and 1 partner of the seventh pair being perfect also. One pair of directives only, connected with the single siphonoglyph. Second cycle consists of 8 pairs, of which only 1 pair is perfect. Third cycle has 14 pairs, only a single mesentery here being perfect. Fourth cycle has 29 small pairs, and a few odd mesenteries belonging to a fifth cycle are present. This scheme of arrangement agrees exactly with the tentacular formula, which runs $7,8,14,29$, etc. Retractors occur on cycles 1-3, not very strongly developed, and diffuse in type (Fig. 4), the muscle processes moderately branched. Fairly large labial and parietal stomata present in the perfect mesenteries, smaller parietal ones in the second and third cycles of mesenteries. Filaments and acontia occur on mesenteries of all cycles, being best developed on the larger ones. Trifoliate region of filament present (Fig. 21), its shape characteristic and compact. Gonads not developed. Longitudinal musculature of tentacles ectodermal, the processes very small and short. Sphincter weak, mesogloeal. Cinclides present, 20 in number, almost all endocoelic, irregularly arranged. One lies in a first-cycle endocoel, 1 in a second-cycle endocoel, 3 in third-cycle endocoels, 13 in fourth-cycle endocoels, 2 in exocoels. In each of 4 fourth-cycle endocoels there are 2 cinclides. No cinclides occur in the part of the body between the sphincter and the margin, i.e. the capitulum; they are scattered. In this specimen the structure of the cinclides is uniform, and in its typical condition is the same as that normally shown by cinclides of the other specimen. The structure may be understood from Fig. 6 . The animal is small and has a thin bodywall, and the cinclides are rather reduced in structure. They are usually neither marked evaginations from the endodermal side nor strong invaginations from the ectodermal, but they tend to be the latter rather than the former, and are sometimes definitely so. There is no actual channel through the epithelium. The typical cinclis, in fact, consists of a definitely organised "soft spot"- - a place where the mesogloea is reduced to little or nothing, and the ectoderm and endoderm covering the thin place both have their cells recognisably differentiated. On the endodermal side there are certain fibres which make a fringe to the mesogloea in the region of the cinclis ; these may be fibres belonging to the endodermal-circular-muscle sheet of the bodywall, somewhat modified in direction by the presence of the cinclis.

The specimen from Valentia was sectionised vertically to show the 
sphincter-structure. The sphincter is very small (Fig. 5), but is definitely mesogloeal, of similar type to that of young $M$. dianthus. It does not occur at the actual margin, because the body is divided into a scapus (lower part), ending in a rim up above, and a capitulum (upper part), the wall of which is thinner than that of the scapus and has a modified ectoderm. The sphincter is in the uppermost part of the scapus, and

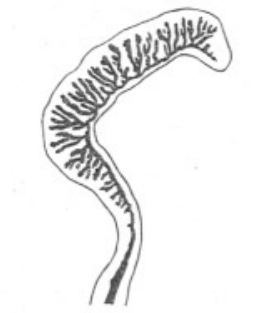

FIG, 4.-Retractor of Metridium pallidum.

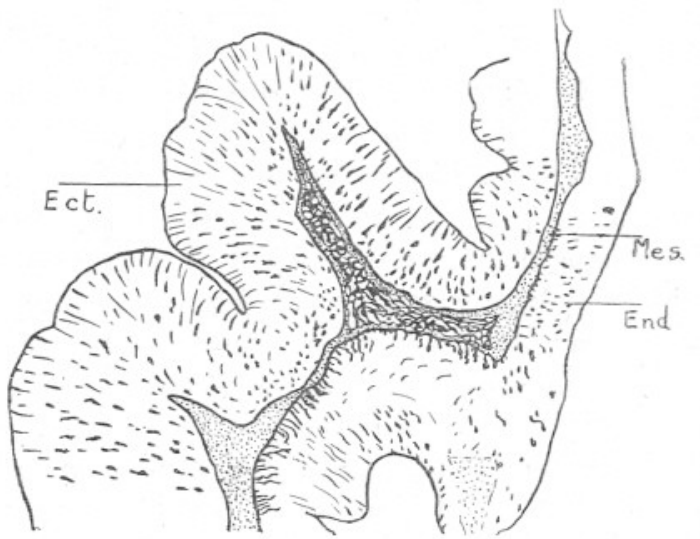

FIG. 5.-Sphincter of Metridium pallidum. Ect. ectoderm : End. endoderm: Mes. mesoglœa.

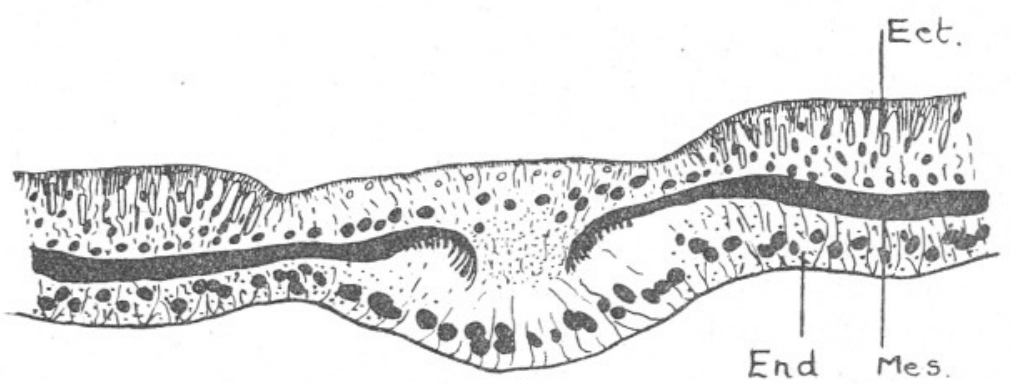

FIG. 6.-Cinclis of Metridium pallidum, shown in T.S.

Ect. ectoderm : End. endoderm : Mes. mesoglœa.

occupies only about 3 per cent of the total height of the bodywall (in the preserved condition).

From the details here set out, as also from the observations of Mr. W. Edgar Evans (1924, p. 185 et seq.), it is evident that this species can no longer be included in the genus Sagartia. The small number of perfect mesenteries, the weak sphincter, the division of the body into a scapus ending in a parapet, above which is a capitulum, are characters foreign to that genus. Its affinities are evidently with Metridium, and it should henceforth be known as Metridium pallidum Holdsworth. It may be 
noted that when alive, $M$. pallidum and the young of $M$. dianthus are extremely similar. Its cinclides, moreover, of a peculiar type, are not like those characteristic of Sagartias, and their general distribution over the scapal part of the bodywall is not like the condition in typical Sagartias. The specimen sectionised vertically is fertile, but, unfortunately, the distribution of gonads is not clear in vertical sections.

\section{Diadumene cincta T. A. Stephenson.}

This species is instituted by T. A. Stephenson on p. 880 of the present issue of this Journal, where its external characters, habitat, and systematic position are dealt with. I am here concerned only with its anatomy, for the study of which I have used 4 specimens from the Plymouth Breakwater.

The following is a description of the individual selected for a series of transverse sections.

Mesenteries in 3 cycles, with additional small mesenteries in upper part of body ; only cycle 1 ( 6 pairs) is perfect. One pair of directives and 1 siphonoglyph only. Retractors present on cycles 1 and 2 , best developed on cycle 1; they are diffuse, the muscle-processes being fairly well branched (Fig. 7). Perfect mesenteries with large labial and parietal stomata; second cycle mesenteries with parietal stomata. The stomata occupy a fairly broad zone. Filaments occur on all older cycles, and are well developed. The trefoil region has a characteristic shape (Fig. 19) and is well developed. Acontia are present on all older cycles, best marked on the larger mesenteries. Longitudinal musculature of tentacles ectodermal, the processes short, thick, and unbranched. No gonads developed. The column is divided into 2 regions, a lower and more extensive scapus, and an upper shorter part or capitulum, which has a thinner wall than the scapus and different ectoderm. Capitulum devoid of cinclides. Scapus plentifully provided with them; they extend throughout its length and are irregularly arranged. They are 126 in number, and of these all are endocoelic except 19; the greatest number occur in third-cycle endocoels, where there may be as many as 10 in 1 endocoel. In structure the cinclides resemble to some extent those of Metridium pallidum, but are rather better developed, perhaps because they belong to a rather larger animal. They differ in appearance in sections, according to whether they are pierced by an actual channel or not. Very few are actually perforated (these having probably been recently used), and these are definitely ectodermal invaginations, with lips of ectoderm, strengthened by mesogloea, projecting inwards into the coelenteron (Fig. 8). The majority, however, have at their best the structure shown in Fig. 9. Here the mesogloea is either actually or virtually interrupted, and the epithelium is intact; but the endoderm 
inside the cinclis is thickened, and the ectoderm sends inwards a little plug of tissue which forces itself through the mesogloea or forces the thin part of the latter inwards when it is not fully perforated. So that here the cinclis in its average state is a partial ectodermal invagination. Fibres such as those mentioned in $M$. pallidum occur here also, on the endodermal side of the mesogloea on either side of the point where it

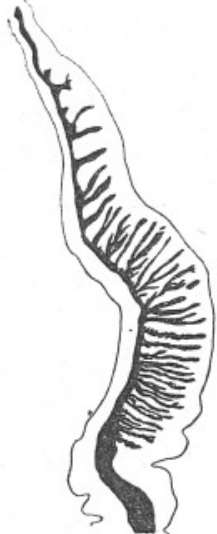

Fig. 7.-Retractor of Diadumene cincta.

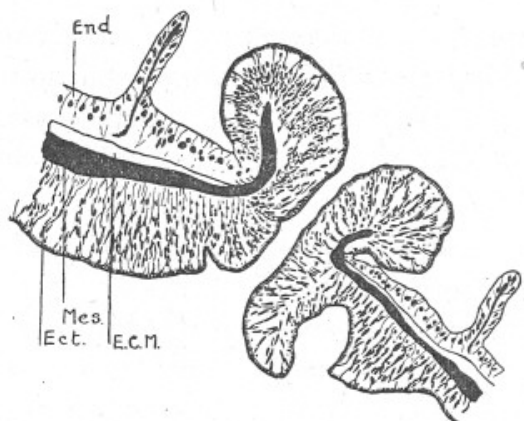

FIG. 8.-Cinclis of Diadumene cincta, shown in T.S.

E.C.M. endodermal circular musele: Ect. ectoderm : End. endoderm: Mes. mesoglœa.

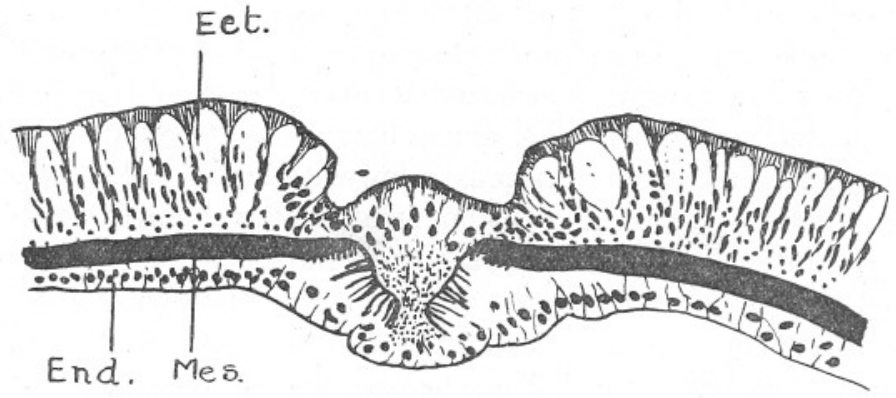

FIG, 9.-Cinclis of Diadumene cincta, shown in T.S

Ect. ectoderm : End. endoderm : Mes. mesoglœa.

is interrupted ; these are shown in Fig. 9, and seem likely to be a modified part of the endodermal circular muscle.

Three other specimens were sectionised vertically with a view to finding the sphincter. There is no trace of a sphincter in any of them. The cinclides seen have typically the same structure in these specimens as in the one described. The specimen described above was not measured during life, but was a moderate-sized one. The largest specimen of the species yet observed had a diameter (disc and tentacles together) of about 
$3 \mathrm{~cm}$., diameter of base 1.8 or $2 \mathrm{~cm}$. Another specimen, not so large, had a total length of $3 \cdot 2 \mathrm{~cm}$, width of body at the same time only $\cdot 35 \mathrm{~cm}$. The large one mentioned would be able to reach a good deal more than $3 \mathrm{~cm}$. in height when well expanded.

\section{Metridium dianthus (Ellis, 1768, p. 436, Pl. 19, Fig. 8).}

The external features of this species are well known. The anatomy of the adult has been described by 0 . Carlgren, 1894, and has been dealt with by others also. I have made a study of the young form, which is very different in appearance from the adult, for comparison with Diadumene cincta, to which it presents some external resemblance. I have used 4 specimens, 2 from Plymouth and 2 from Millport, all of them as nearly as possible of the same size as an average example of Diadumene ; some of them were also of the orange colour variety, which most nearly resembles that species in appearance. The following is a description of an individual which was cut into a series of transverse sections.

Six pairs of perfect mesenteries. One pair of directives and 1 siphonoglyph only. Four complete cycles of imperfect mesenteries, with other small additional pairs developing in upper part of body. Mesenterial formula, therefore, according to the plan 6p., 6p., 12p., 24p., 48p., 96p. ; but the sixth cycle is not fully represented, and the scheme is interfered with by an irregularity in 2 sectors opposite the directives, where the number is reduced. Cycles 1-3 inclusive bear well-developed retractors, and the larger mesenteries of the fourth cycle bear feebly developed ones. Retractors concentrated-diffuse in type (Fig. 13), the processes very high and fairly well branched. Mesenteries of cycles $1-4$ have parietal stomata, very large ones in cycles 1 and 2. Perfect mesenteries with oral stomata also. Filaments occur on all cycles, and the typical trefoil region is compact and rather like that of $M$. pallidum (Fig. 20). Acontia are borne by cycles 1-4 inclusive. Longitudinal musculature of tentacles ectodermal, the processes short and unbranched. Sphincter occupying about $4 \frac{1}{2}$ per cent of total height of body (preserved). Cinclides occur scattered fairly evenly throughout the scapus; there are about 30 of them, 5 in endocoels and 25 in exocoels. Carlgren (1894, pp. 103 and 105) notes that in the adult form the cinclides are formed chiefly by endodermal evagination, and occur mostly in exocoels. In this specimen some of the cinclides are endodermal evaginations, but more of them are formed mainly by ectodermal invagination, so that we have 2 types in the same individual, the 2 types not separated into zones, but occurring erratically.

In other specimens the cinclides show the same kind of structure. In all specimens which I have examined, both ectodermal invaginations 
and endodermal evaginations occur in the same individual. Few of them have a definite canal going all the way through the bodywall, but such a canal may occur. Fig. 10 shows a cinclis, an endodermal evagination which has broken through the mesogloea, and has in it a canal running out from the endodermal side (inner opening of this canal is in another

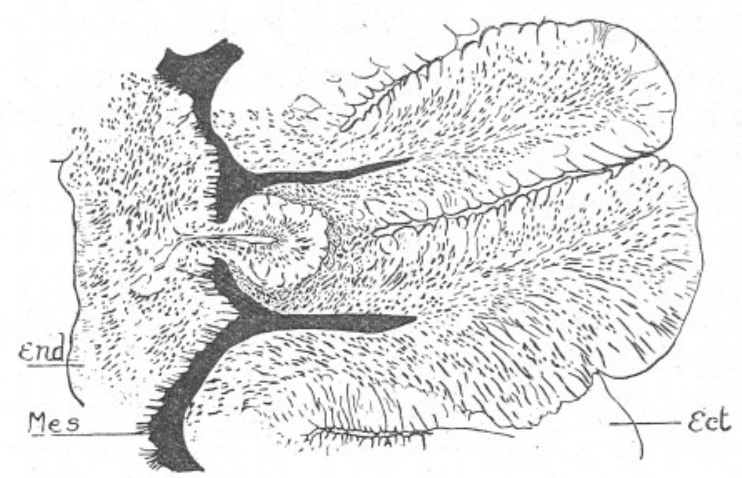

FIG. 10.-Cinclis of Metridium dianthus, shown in L.S. Ect. ectoderm : End. endoderm : Mes. mesoglœa.

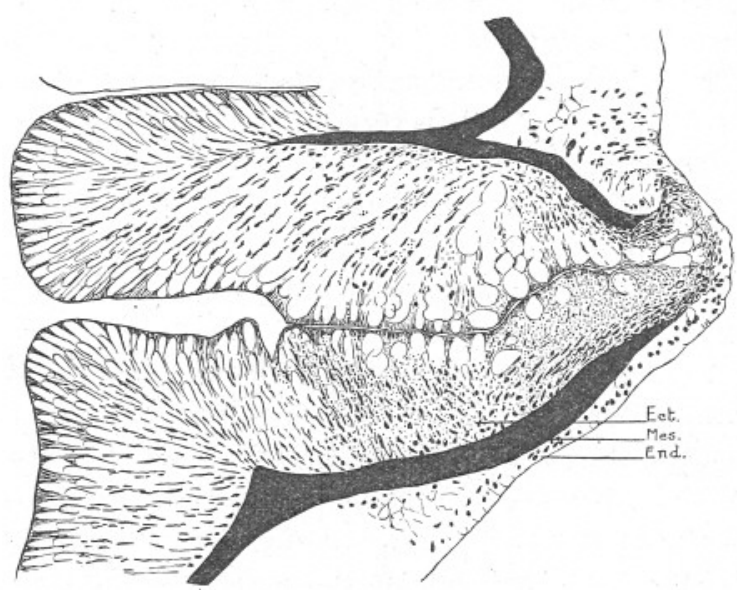

FIG. 11.-Cinclis of Metridium dianthus, shown in L.S. Ect. ectoderm : End. endoderm : Mes. mesoglœa.

section) and ending blindly externally. Fig. 11 is another cinclis from the same individual, and this one is an ectodermal ingrowth penetrated by a canal all the way through, though the canal is not wholly shown in any one section.

The sphincter was observed in all 4 specimens. It is mesogloeal in all of them, and in the 2 from Plymouth it is well developed and lies in a 
well-marked thickening of the bodywall, whereas in the Millport ones it is very insignificant (Fig. 12) and the thickening is slight.

The above examination establishes the fact that Metridium has a mesogloeal sphincter when at the same size as Diadumene cincta, whereas the latter has none at all; that the cinclides in Diadumene are predominantly endocoelic, in young Metridium the opposite; the cinclides are, besides, different in detailed structure in the 2 forms. In the 2 specimens cut transversely, the number of tentacles and mesenteries in the Diadumene was less than that in the Metridium of, roughly, the same

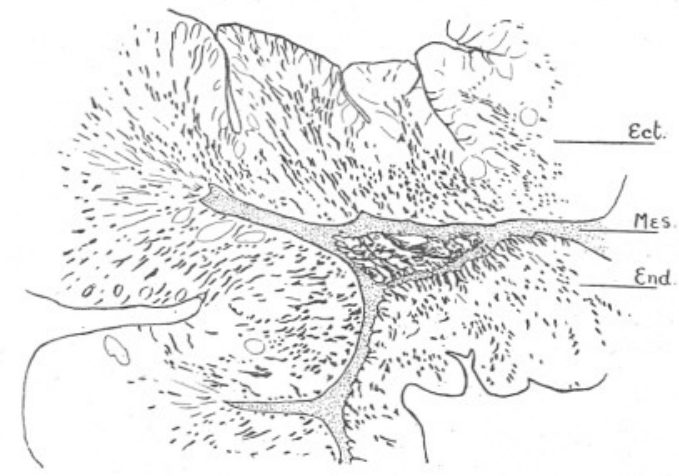

FIG, 12.-Sphincter of Metridium dianthus.

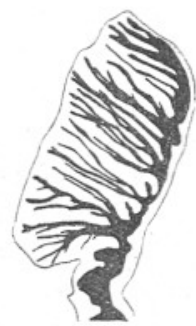

FIg. 13. Retractor of Metridium dianthus.

Ect. ectoderm : End. endoderm : Mes. mesoglœa.

size; Diadumene can have more tentacles than the one sectionised, the largest specimen yet observed had 6 cycles of them and a few odd ones, though the numbers in the various cycles were not at their full complement; but Metridium as it grows up can far exceed this.

\section{Gephyropsis dohrniI (von Koch, 1878, p. 78).}

This species has been described by von Koch (1878), by Andres (1883, p. 381 ), and by Haddon (1889, p. 325), but these descriptions deal mainly with external features. The form is well known at Plymouth, where it occurs on Gorgonia verrucosa. I have a series of transverse sections of a medium-sized Plymouth specimen. The length of the animal's longest axis (along the Gorgonian) is $\cdot 7 \mathrm{~cm}$. Width of body at the same place $\cdot 4 \mathrm{~cm}$. (when preserved). The region of the ectoderm which, during life, is in contact with the Alcyonarian (i.e. the basal disc) is specialised, being thickened and densely charged with gland-cells. Arrangement of mesenteries irregular and not reducible to a definite formula. There are 3 pairs of directive mesenteries, corresponding to 3 siphonoglyphs. Perfect mesenteries $10 \frac{1}{2}$ pairs, running as follows with relation to the directives: D3 D1 $\frac{1}{2}$ D3. There are 2 cycles of imperfect mesenteries, and a 
few extra pairs beyond these, mostly developed aborally. Perfect mesenteries with oral and parietal stomata; most of the second cycle mesenteries with parietal stomata. Retractors occur on the perfect mesenteries and the larger imperfect ones; they are quite diffuse, feebly developed, and with low processes (Fig. 15). Filaments are present on all older mesenteries; the trefoil region is shown in Fig. 23. Acontia also occur on the older mesenteries. The non-directive perfect mesenteries are fertile, so are the larger imperfect ones. Directives sterile. Longitudinal musculature of tentacles ectodermal, the processes short,

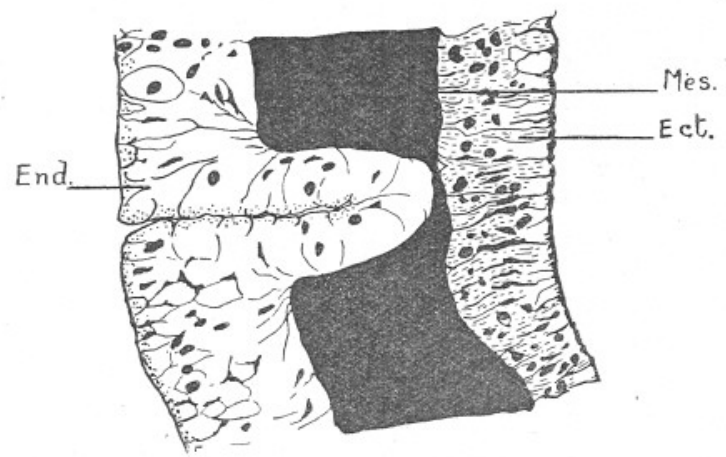

FIG. 14.-Cinclis of Gephyropsis dohrnii, shown in T.S. Ect. eetoderm : End. endoderm : Mes. mesoglœa.

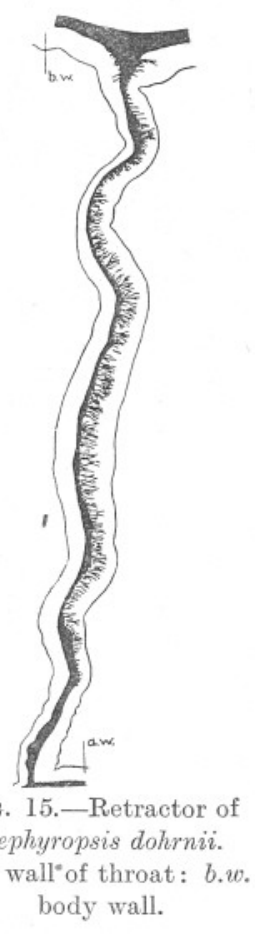

thick, and branched. Sphincter mesogloeal, strong, occupying about $11 \frac{1}{2}$ per cent of total height of bodywall (preserved). Cinclides present, 3 in number only. One occurs in each of 2 directive endocoels, and 1 in a non-directive endocoel. They are large, and are endodermal evaginations of a perfectly clear type, completely interrupting the mesogloea. The drawing in Fig. 14 is of a section passing slightly to one side of the actual point of interruption of the mesogloea, but showing the canal which runs outward from the endodermal side.

The name of this species, hitherto known as Gephyra dohrnii, has to be changed, according to Carlgren, because the name Gephyra is preoccupied. It becomes Gephyropsis dohrnii. 
It is difficult to decide the affinities of Gephyropsis exactly. Carlgren has just published a paper on this question (1925, p. 1), and concludes that there is no reason for erecting a separate family for Gephyropsis and its relative Amphianthus, at present; and that the group of anemones with acontia and basilar muscles, for which he still keeps the name Sagartiidæ, is so far too little known to be accurately subdivided. Carlgren's account of the genus Gephyropsis agrees in the main with that given here, but he states that the genus has no cinclides. This is incorrect for British specimens at any rate. The one here described has perfectly clear and well-preserved cinclides about the presence of which there is not any doubt. Moreover, in living specimens of the species cinclides can be plainly seen, sometimes 2 on 1 directive endocoel.

Although not eligible for the family Chondractiniidæ as at present defined, Gephyropsis presents certain definite affinities with that group and is probably more connected with them than with the Sagartiidæ (sens. strict.), as represented by Sagartia and its immediate neighbours.

\section{ADDITIONAL NOTES.}

The following notes include a few facts connected with forms whose general anatomy is either already known, or which it has not been possible to study more fully.

\section{Halcampa arenaria (Haddon, 1886, p. 616).}

Haddon defined the genus Halcampa (1889, p. 333) as possessing " no sharply-defined circular muscle," i.e. no sphincter. It has since been shown by Carlgren (1900, p. 1171) and T. A. Stephenson (1918, p. 9, and 1920, p. 441) that there is a small mesogloeal sphincter in $H$. chrysanthellum, and the genus has been redefined as possessing such.

I have been able to examine a specimen of $H$. arenaria, collected at Valentia by Miss Delap, and this also possesses a mesogloeal sphincter (Fig. 16). This confirms a recent statement made by Carlgren (1921, p. 122) to the same effect.

\section{Sagartia viduata (Müller, 1776, p. 231).}

I have examined some cinclides of this form, from a Plymouth specimen, for comparison with those of other species. The cinclides seen were all clearly and markedly endodermal evaginations, such as that.shown in Fig. 17. This is the direct opposite of the cinclides observed by Carlgren (1894, p. 91, and Pl. VI, Fig. 7) in S. viduata, which were strongly ectodermal invaginations. There can be no doubt, however, of the nature of the cinclides in the Plymouth form. It is not impossible that the more northern one used by Carlgren is another species than the one- 


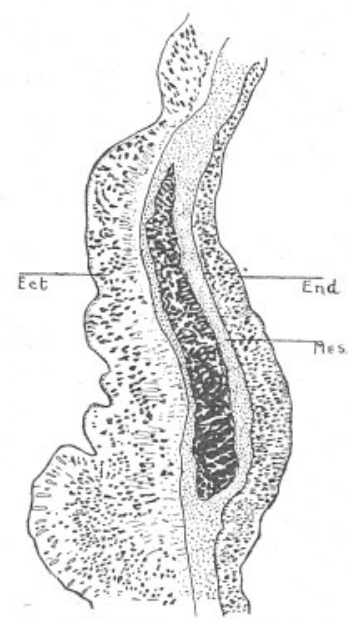

FIg. 16.-Sphincter of Halcampa arenaria.

Ect. ectoderm : End. endoderm : Mes. mesogloea.

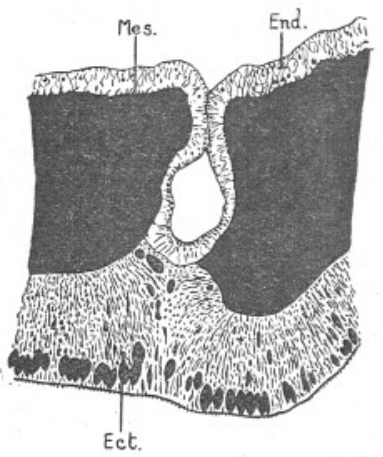

FIG. 17.-Cinclis of Sagartia viduata, shown in T.S.

Ect. ectoderm: End. endoderm : Mes. mesoglœa.

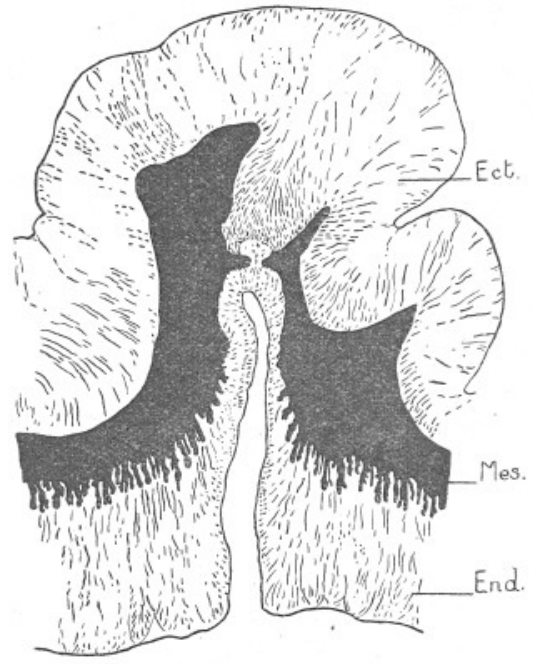

FIG. 18.-Cinclis of Sagartia rosea, shown in T.S.

Ect. ectoderm : End. endoderm: Mes. mesogloea. 
usually called by that name in this country - a suggestion which Carlgren himself has recently made (1924, p. 246).

Sagartia rosea (Gosse, 1853, p. 90, Pl. I, Figs. 5 and 6).

I can contribute a few facts towards the anatomy of this species, as the beginning of a study of its relationship to $S$. miniata, S. nivea, and S. venusta, which is not yet complete.

$S$. rosea has the same general characters as the other species mentioned. The longitudinal musculature of the tentacles is ectodermal. Numerous mesenteries are perfect, the retractors are strong-diffuse, acontia are present. The cinclides belonging to the upper part of the body are in all cases examined, endodermal evaginations in principle ; one of them is illustrated in Fig. 18. In one specimen sectionised there were a considerable number of them, in endocoels, in a fairly broad zone a little below the sphincter. The specimens used were from Lydstep, Pembrokeshire.

\section{DISCUSSION.}

\section{Mesenteric filaments.}

The form of these is very varied in different groups of Anthozoa, and is especially interesting in the case of the Ceriantharia. In the Actiniaria the structural type is almost uniform, the great majority of forms having one general pattern of filament, and only a few more or less primitive forms having a less developed type. The majority of forms possess in three-fold region on their filaments, consisting of a median " cnidoglandular" epithelial cord and of two lateral cords of purely ciliated epithelium; this structure giving a trifoliate outline to a transverse section. In different Actinians the exact form of this trefoil varies very considerably; the shape of each portion varies, and so do the relative proportions of one part to another. There may be, too, on either side of the point where the trefoil joins the free edge of the mesentery a region presenting a network-like appearance-the "reticulate tract"; when these tracts are well developed the filament is rather five-fold than three-fold. In studying the anemones dealt with in this paper, I have been struck by the differences in pattern of the trefoil region of the filaments, and especially in the variation of the reticulate region. The pattern in any individual specimen appears to be constant, and so far as I have seen it holds good from one specimen to another. If it is constant throughout a series of individuals it would provide a rather useful character towards the determining of species from preserved material. But a much wider material than I have been able to use would be needed to confirm its specific constancy. The various filaments illustrated in this paper give 
some of the variations in pattern to which I refer. Among those species which I have here examined the ones belonging to the Sagartiidæ (sens. strict.) have well-marked reticulate regions on their filaments; the Metridiid forms less marked ones or practically none.

\section{Cinclides.}

One of the objects of this paper has been to make out the structure and distribution of the cinclides in the species involved, with a view to finding out the value or otherwise of these structures as classificatory

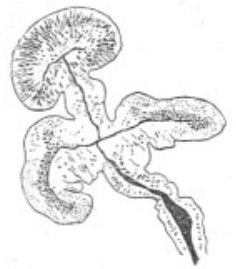

Fig. 19.-Trefoil region of filament of Diadumene cincta.

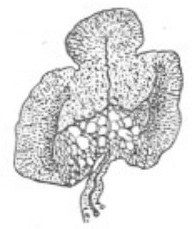

FIG. 22.-Trefoil region of filament of Sagartia rosea.

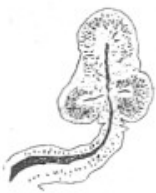

Fig. 20.-Trefoil region of filament of Metridium dianthus.

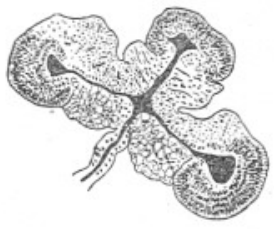

Fig. 23.-Trefoil region of filament of Gephyropsis dohrnii.

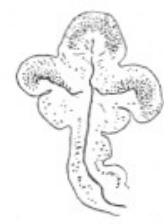

Fig. 21.-Trefoil region of filament of Metridium pallidum.

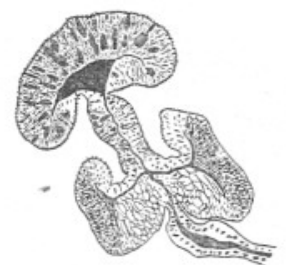

FIc. 24.-Trefoil region of filament of Sagartia viduata.

characters. The meaning of the cinclis-structure has also been given attention.

The genus Sagartia is a large one, and it is impossible to gain a final arrangement or understanding of it until more is known of it, and among other things the cinclides must be understood. The genus has been cleared up recently, to some extent, by the removal from it of S. lucia by McMurrich (1921, p. 729); and the present paper goes a step further by transferring $S$. pallida to Metridium. In the type species, S. miniata, the cinclides have been described by T. A. Stephenson (1920, pp. 446 et seq.). In this form there are 2 sets of them; 1 series occurs high up on the bodywall, just below the sphincter, the other set low down, immediately above the margin of the pedal disc ; the 2 sets being separated by a cinclis-free zone. The upper-zone cinclides are frequently endodermal 
evaginations in structure, those of the lower zone often being, on the contrary, ectodermal inpushings. In my own work on $S$. coccinea, $S$. viduata, and $S$. rosea I have been able to confirm this to some extent. In all of them there is an upper zone of cinclides which are typically endodermal evaginations. The lower-zone series requires further investigation than I have yet been able to give it, but I could detect no signs of it in $S$. coccinea, this being perhaps due to the small size of the specimens. Where it has been seen so far it has been in larger ones.

The work so far done on British Sagartias tends, therefore, to show that they all follow one kind of plan; but this conclusion is badly shaken by the conditions which Carlgren found in forms from further north, where, in $S$. viduata and $S$. undata from Gullmarfjord, etc., the upper zone cinclides were ectodermal invaginations. Whether this indicates simply that the cinclides are thoroughly variable, even within one and the same species, or whether a really extensive study will reveal a constant plan, it is as yet too early to say. The northern species are not necessarily the same as the British ones.

In Diadumene cincta and Metridium pallidum we find a plan contrasting with that of Sagartia. Here the cinclides are confined to the lower region of the body (the scapus), over which they are spread fairly evenly without being divided into zones, and they tend to follow a single type of structure only. This structure is rather curious, and not quite like that found in Sagartia.

In young Metridium dianthus the cinclides are either invaginations or evaginations, mingled haphazard.

At present it looks as if the structure and arrangement of cinclides will give a certain amount of guide to affinities, but that there is too much probability of variation to make it safe to build systematic characters upon them until more is known. In some cases they are useful, however, as in the instance of the contrast between $D$. cincta and $M$. dianthus, in the former of which the cinclides are predominantly endocoelic, in the latter the opposite. This is quite an arbitrary difference, and should prove diagnostic. It may also be found that in some forms the cinclides occur most extensively in endocoels of a given cycle of mesenteries, in other forms a different cycle or cycles being chosen, e.g. in $D$. cincta the greatest number occur in third-cycle endocoels, in $S$. coccinea all are in first- or second-cycle endocoels.

With regard to the function of cinclides, T. A. Stephenson has shown (1920, pp. 446 et seq.) that they appear in some cases to act as safetyvalves, allowing fine jets of water to escape from the coelenteron of the anemone when the latter is obliged for any reason to contract very rapidly; they supplement the mouth as a means of exit and prevent rupture of the bodywall. In all cases they are probably connected in 
some way with water-currents. My own work has extended some of the observations made in the paper mentioned, where it was noted that cinclides are not necessarily channels through the bodywall, as has usually been thought, but may be simply organised "soft spots" where the mesogloea is interrupted and the epithelium, etc., more or less modified; spots which can rupture neatly and without harm to the animal when needed as safety-valves. In my material I have found that cinclides of this kind are very common, and that in $D$. cincta and $M$. pallidum especially they are practically the normal condition. It may be that they are the typical variety for certain types of bodywall. After a cinclis has been used, it is not known whether it heals up again or regularises its channel. It may do the former in some cases and the latter in others.

\section{LITERATURE.}

Andres, A. Le Attinie. Mem. R. Accad. Lincei, Rome, Ser. 3, Vol. XIV, p. $211,1883$.

Carlgren, O. Studien über Nordische Actinien. Inaugural-Dissertation zur Erlangung der Doctorwürde, etc., zu Upsala. Stockholm, 1894.

Carlgren, O. Über Pentactinia californica, n. gen., n. sp. Ofv. af Kongl. Vetenkaps-Akad. Förhandl., No. 10, p. 1165. Stockholm, 1900.

Carlgren, O. Actiniaria. Part 1. The Danish Ingolf-Expedition, Vol. V, No. 9. Copenhagen, 1921.

CARLgren, O. Actiniaria from New Zealand and its Subantarctic Islands. Papers from Dr. Th. Mortensen's Pacific Expedition, 1914-16, XXI. Vidensk. Medd. fra Dansk. naturh. Foren., Bd. 77, p. 179, 1924.

Carlgren, $\dot{0}$. On the Actinian family Amphianthidæ. Arkiv for Zoologi., Bd. 17B, No. 4, p. 1. Upsala, 1925.

Ellis, J. An Account of the Actinia Sociata, or Clustered Animalflower, etc. Phil. Trans., Vol. LVII, 1767, p. 428. London, 1768.

Evans, W. Edgar. The Occurrence in the Forth of the Sea-anemone Sagartia pallida (Holdsw.) ; with Remarks on its Anatomy, Reproduction, and Affinities. The Scottish Naturalist, 1924, p. 185.

Gosse, P. H. A Naturalist's Rambles on the Devonshire Coast. London, 1853.

Gosse, P. H. Synopsis of the Families, Genera, and Species of the British Actiniæ. Ann. Mag. Nat. Hist., 3, 1, p. 414.

Gosse, P. H. A History of the British Sea-anemones and Corals. London, 1860. 
Haddon, A. C. First Report on the Marine Fauna of the South-West of Ireland. Proc. R. Irish Acad., Ser. 2, Vol. 4 (Science), p. 599. Dublin, 1884-8.

Haddon, A. C. A Revision of the British Actiniæ. Part I. Sci. Trans. Roy. Dublin Soc., Series II, Vol. IV, p. 297. Dublin, 1889.

Holdsworth, E. W. H. Description of Two New Species of Actinia from the South Coast of Devon. Proc. Zool. Soc., Part 23, p. 235. London, 1855.

Koch, G. von. Zur Phylogenie der Antipatharia. Morph. Jahrbuch, IV, p. 74. Leipzig, 1878.

McMurrich, J. P. Note on the Systematic Position and Distribution of the Actinian Sagartia lucice. Proc. Zool. Soc., p. 729. London, 1921.

Müller, O. F. Zoologiæ Danicæ Prodromus, seu Animalium Daniæ et Norvegiæ, etc. Havniæ, 1776.

Stephenson, T. A. Actiniaria. Brit. Antarct. ("Terra Nova") Expedition, 1910. Nat. Hist. Reports, Zoology, Vol. V, No. 1, p. 1. London, 1918.

Stephenson, T. A. On the Classification of Actiniaria. Quart. Journ. Micros. Sci. : Part I. Vol. 64, Part 4, 1920, p. 425. Part II. Vol. 65, Part 4, 1921, p. 493. Part III. Vol. 66, Part 2, 1922, p. 247.

Walton, C. L. Notes on some Sagartiidæ and Zoanthidæ from Plymouth. Journ. Mar. Biol. Assoc., Vol. VII, No. 2, p. 207. Plymouth, 1908. 